\author{
Jelena Dinić ${ }^{1}$ \\ Faculty of Philosophy \\ University of Niš
}

\title{
Value Orientations of Highly Educated Migrants from Serbia ${ }^{2}$
}

International migration of the highly educated has always been a characteristic of academia, however, specific circumstances in the Balkans in recent years, marked by wars and economic crisis, have additionally contributed to a large outflow of highly educated people from Serbia. The aim of this study was to identify value systems among the highly educated migrants from Serbia. Living in extremely complex social situations, having to speak two or more languages and being adapted to living in different cultures, different political and social environments might influence migrants' value systems. For this purpose, a questionnaire has been constructed consisting of standardized scales - Value Orientation Scale (Kuzmanović 1995), Postmaterialism Scale (Inglehart 2000), and Social Distance Scale (Bogardus 1933). Our sample consisted of 327 highly educated emigrants who responded to an online survey.

The results show that our sample characterizes expressed openness to the world, equality of genders, secular-rational and self-expression values. On the other hand, lower levels of conformism, religiousness, authoritarianism and social distance are detected. Our assumption is that the results obtained may be a consequence of the migrant lifestyle and in this regard are consistent with the new approach in the study of migration - transnationalism.

Keywords: migration, highly educated, value orientations, Serbia

\footnotetext{
${ }^{1}$ Contact: Jelena Dinić, jelendzi@hotmail.com

2 This paper, and the results of the research presented in the paper, represent one segment of the author's research conducted for the purpose of preparing a doctoral dissertation, which was defended at the University of Niš.
} 


\section{Introduction}

In the modern world, marked by the processes of globalisation, migrations are not a novelty. Life stories that are not connected to the borders of a particular national state have already become a normal occurrence. At the end of the $20^{\text {th }}$ century this kind of migrations particularly increased, because, in their search for a better life, a large number of people from non-developed countries were trying to enter developed countries, both legally and illegally. However, while economic and political reasons of migrations have often been analysed, a personal impact has only been rarely assessed. Moving from one country to another and then returning to the home country is a social phenomenon which is widely spread, which is why it is necessary to give more attention to the migrant perspective, specific interests, living conditions, as well as the achievements of migrants. More and more migrants in the modern world lead double or triple lives, they often speak two or more languages and they are adapted to life in different cultures, different political and social environments. Being that the formation of values is influenced by both individual and social factors, what emerges is a significant question regarding what kind of value system is obtained or built by emigrants in the event of extremely complex social condition, which is reflected in a conflict and complex offer of social values. In this sense, scientists and research professionals, the highly educated, who make the centre point of progress and, needless to point out, they are the only ones who can provide the optimal development trend in the future times of the technological-information revolution become very important. The study of their attitudes, opinions, and value orientations contributes to the understanding of their lifestyles, needs, and changes which occurred, and therefore, it can also contribute to the understanding of different ways of their gathering.

This paper explores precisely the value orientations of highly educated emigrants from Serbia. The first part of the paper presents the current situation in Serbia. The second part deals with the significance of the study of value orientations in the context of migrants, as well as with the new theoretical approaches to this phenomenon. In the third part of the paper, the results obtained in our research are presented.

\section{Serbia, emigration area}

It is often said that Serbia is a typical emigration area (Nikitović 2011; Bobić, Babović 2013). However, the events in the 1990's caused one of the biggest outflow of people from the country. Unofficial evaluations show that today around four (and even six) million people of Serbian origin live outside the borders of the Republic of Serbia. 
Serbia is a former republic of the Socialist Federative Republic of Yugoslavia and is currently in the process of transition. Transition in Serbia is characterised by the fact that it was, and still is, marked by a slow or frozen transition. At the beginning of the 1990's it could be noticed that the country, as stated by Lazić (2000), was going through a "fast degeneration of the process of changes" followed by collapse of the economy, which made the majority of the population poor, developed the criminal class, and established authoritarian oligarchy. During the 1990's and the economic crisis, social disturbances, wars, a large number of experts, people with high qualifications and skills left Serbia. The last decade in Serbia has been particularly marked by a large brain drain. In the period from 1990 to 2000, the exodus of citizens with university education, in that period, included probably over 30,000 individuals (Grečić 2002, 2009). According to the data from 2005, the former state of Serbia and Montenegro had 149,065 emigrant professionals which put it on the $24^{\text {th }}$ place on the list of countries with the largest number of emigrated professionals with higher education (Docquier, Rapoport 2005 as cited in Pavlov 2009). The brain drain trend continues today as well.

Among those highly educated individuals who left Serbia, many did not get proper employment, according to their knowledge and skills (brain waste) and they fulfil the local job market by taking up occupations in short supply. Besides this hard circumstance, many individuals suffer due to the feeling of loneliness, social isolation and the loss of identity. None of us can exist only for ourselves, as individuals, but we also have to be connected to others, to be a part of the collective or a group, such as family, relatives, friends, colleagues, neighbours, nation, ethnic group, religion, culture or civilisation. As pointed out by Bobić (2009), the collective identity is further reflected in the generation continuity, shared feelings, thoughts and memories of the ethnic, that is, national past.

\section{Value Orientations of Emigrants}

The study of value orientations in the context of migrants is significant for several reasons. Values are connected to psychological traits, abilities, habits, interests, and they affect behaviour, actions and reactions of individuals. Values can be a strong motivational factor which affects one's feelings and opinions, and in some circumstances, an individual can also take great sacrifices for his/her values. Being that values are acquired during the process of socialisation, over time they become cultural standards, which significantly affect one's view of the world.

One of the reasons why researchers are interested in values is their relative stability, which enables the prediction of future behaviour of people and social movements, even more successfully than on the basis of some other dispositions, which is very significant for different populations and groups, especially emigrants 
(Berry 1997, 2002, 2005; Bhugra, Beker 2005). It was Rokeach who pointed out that the stability of values was not absolute, because social and personal development would not be possible if the values were unchangeable, but also that neither identity, nor social stability would be sustainable if values were so prone to changes (Rokeach 1973; Alargić 2012; Bešić 2014). Considering the fact that one of the basic characteristics of values is their relative stability, their study enables better predictability of behaviour than some other personality dispositions (Pantić 2003).

Inglehart's key thesis in his theory of modernization also rests on the idea of relative stability of values. The main idea underlying his thesis is that advanced industrial societies are going through almost linear change from materialistic to postmaterialistic values (Inglehart 1971; Inglehart, Flanagan 1987; Inglehart, Baker 2000; Hansen, Tol 2003; Bešić 2014;). Changes in value orientations of individuals lead to changes in the dominant values at the population level. In his works Inglehart proceeds from the socialization hypothesis according to which the values are adopted in the formative period, and from the scarcity hypothesis according to which the lack of material and financial security implies a tendency towards materialistic values (Abramson, Inglehart 1992). In that sense, social change is reflected in the fact that earlier, economically insecure and traditional societies gradually become more tolerant and more egalitarian. Namely, reduced economic concerns, as well as economic and physical insecurity and more secured survival, would influence materialistic values to be replaced by non-economic concerns, that is, by postmaterialistic values. The most important values then become social equality, participation in social decision making, greater freedom, self-expression and improvement of the quality of life (Davis, Davenport 1999). Changes in predominant views of the world caused by increasing levels of education, the spread of mass communications and information that increase the intellectual skills of people, lead to the material, intellectual and social autonomy of the individuals, resulting in a reassessment of authority over people and a tendency towards individual freedom and equality, and a shift from materialistic to postmaterialistic values (Inglehart, Welzel 2005; Pavlović 2009). The development of these values further contributes to changes in society, and changes in social, gender, religious and other norms (Inglehart, Abramson 1999; Davis, Devenport 1999). Change toward postmaterialistic values consists of two dimensions of cross-cultural variations: 1) the change of traditional to secular-rational values, and 2) the change from survival to self-expression values (Norris, Inglehart 2009). However, on the basis of his most recent research, he revised his theory of modernization and pointed out that economic development would only potentially influence the development of postmaterialistic values, and that cultural modernization is a reversible process. Contemporary values have contradictory nature, meaning that traditional values do not disappear, rather they have an impact on the acceptance of new values, which often leads to a combination of traditional, modern and postmodern perspectives 
(Inglehart, Baker 2000; Inglehart, Welzel 2010 as cited in Gavrilović, Stjepanović Zaharijevski 2012).

Rudnev (2014) states that values are stable when living conditions of individuals are static and they live in the society which does not change. However, such conditions, almost do not exist today in the modern society. Today, societies change very quickly. In the modern world, where the social and cultural changes are very rapid, and transport and migrations have become much easier, individuals have to learn how to cope with these conditions. They have to be able to change not only their behaviour, but also their attitudes, and deeper aspects of their personalities, such as values. This particularly refers to migrants who change their socio-cultural milieu in quite an extreme manner. These new socio-cultural conditions can affect values of individuals. The acquired values from the home culture, after being confronted with the values of the society to which the migrant goes, can be in opposition, which can result in the change of individuals' values (Dinić 2017).

Earlier concepts on migration imply a one-way direction within which migrants acquire cultural, economic and political patterns of the host country, thus losing the patterns which are characteristic for their home country. By transferring from one nation or culture into another, migrants bring with them their knowledge, beliefs, values, and, in their desire to develop a sense of belonging, their cultural identity will probably change, and the values of the dominant cultural group, that is, the host country, will prevail (Bhugra 2004; Berry 1997, 2002, 2005). However, with the fast changes in technology and forms of communication, migrants often become a part of two or more environments, each with different social, cultural and economic relations. Actually, more and more migrants lead double or triple lives. Very often, they speak two or more languages and they are adapted to life in different cultural, political and social environments (Predojević-Despić 2009; Williams, Thornton and Young-DeMarco 2014; Dinić 2016). Williams and associates (2014) point out that changes in value orientations occur as a consequence of different experiences, and that in order to predict the way in which they will change, what migrants adapt to should be taken into consideration. In this sense, migrants do not have to adapt to a certain culture, but they can accept the migrant lifestyle, which also affects the value orientations.

That is why today a large number of scientists and researchers shift towards the transnationalist approach. Influenced by accelerating globalisation over the last two decades, the transnationalist approach has been developed as one of the main theoretical frameworks for understanding contemporary international migration (Kurekova 2011). The transnationalist approach synthesises previous approaches of researching migration flows, so instead of focusing on the causes of migration, it points to the development of transnational social spaces which overcome the borders of national states, within which migrants build and develop thick, strong networks with which they connect their home and host countries through 
their everyday activities (Basch, Glick Schiller, Szanton-Blanc 1994; Glick-Schiller, Basch, Szanton Blanc 1995; Portes 1997; Robinson 1998; Vertovec 2001; Kivisto 2001; De Haas 2005; Predojević-Despić 2009; Flanagan, Lee 2010; Faist 2010). The observation of contemporary migrations through the prism of the transnationalist approach enables a wider view, not only of the migration phenomenon but also of the way in which migrants adapt, as well as of the effects which migrations have on both home and host countries (Kurekova 2011).

\section{The Research Methodology}

There are few researches on value orientations of emigrants, and there is none that refers to the Serbian diaspora. This was the motive for initiating this research. Hence, the conducted research was of descriptive and exploratory type. The research was realized in the period from October 2016 to August 2017. It represents an attempt to acquire additional knowledge on highly educated members of the Serbian diaspora, in hope that this would create a more comprehensive picture of their value orientations. The main idea behind this exploratory research was to identify the basic tendencies, so that the indicated tendencies could be more accurately measured in any possible future research. In accordance with the selected problem and defined subject, the overall goal of the research was to determine the expression of different value orientations among Serbian highly educated emigrants and identify the values to which diaspora members give the greatest significance.

For operationalisation of value orientations, standardised scales were used:

- Kuzmanovićs test of value orientations (1995), an instrument which consists of eight scales made of 6 items, each of which measures one of the value orientations. These are: openness to the world, religiousness, egalitarianism, conformism, authoritarianism, gender equality, general activism, social activism; a higher score on the scale indicates higher expression of a value orientation. The results on the scales range from 6 to 30 and the theoretical mean value is 18 .

- Iglehart's postmaterialism scale (2000), which measures traditional versus secular-rational values ( 24 items scale and the score ranges from 28 to 120 with theoretical mean value of 72 ) and survival versus self-expression values (29 items) (scale ranges from 45 to 145 with theoretical mean value of 87); a higher score indicates higher expression of traditional, that is, survival values.

- Bogardus' social distance scale (1933) in the form used in the European Value Survey (EVS 2008). The respondents were offered to evaluate what kind of relations they would engage in with the members of certain social groups (individuals with a criminal past, people of different race, alcoholics, immigrants, drug addicts, emotionally unstable people, people with AIDS, 
homosexuals, people of different religious affiliation, Jews, Roma, Muslims). The relations used included: "I would rather they did not live in the country I live in", "I would rather they did not live in my neighbourhood", "I would accept him/her as an acquaintance", "I would accept him/her as a neighbour", "I would work with him/her in the same office", "I would accept him/her as a friend", "I would marry him/her". The Bogardus social distance scale is cumulative (meaning that the acceptance of a certain claim implies the acceptance of those which it follows); therefore, a higher score on the scale indicates higher social distance. The results on this scale range from 12 to 84 and the theoretical mean value is $48^{3}$.

Before the analysis of the data, the reliability of the used instrument has been verified on the sample of our respondents. For this purpose, we have used the Cronbach's alpha of internal consistency (Table 1). On the sample of our respondents, it has been obtained that scales which measure value orientations mostly have satisfying reliability $(\alpha>0.70)$, except for the following value orientations: openness to the world, egalitarianism and survival/self-expression values, which have lower, but satisfying reliability $(\alpha>0.60)$.

Table 1 .

Scales reliability

\begin{tabular}{|l|c|}
\hline \multicolumn{1}{|c|}{$\mathrm{N}=327$} & $\alpha$ \\
\hline Openness to the world & 0.646 \\
\hline Religiousness & 0.868 \\
\hline Egalitarianism & 0.672 \\
\hline Conformism & 0.710 \\
\hline Authoritarianism & 0.789 \\
\hline Gender equality & 0.755 \\
\hline General activism & 0.740 \\
\hline Social activism & 0.815 \\
\hline Traditional/secular-rational values & 0.878 \\
\hline Survival/self-expression values & 0.668 \\
\hline Social distance & 0.883 \\
\hline
\end{tabular}

Source: Author's own study.

3 Taking into account that all social groups covered by this scale represent the most frequently discriminated, marginalised social groups, we have calculated in our research the total score for all the above-mentioned items. This form of scale has already been used in previous studies of social distance (see: Chukwujekwu, C.D., Chukwujekwu C. J., Olose, 2016). 


\section{Sample}

Our sample included 327 highly educated members of the Serbian diaspora ${ }^{4}$ who responded to an online survey. Considering the fact that the actual number of highly educated emigrants from Serbia is unknown and that most often estimates are stated, whereby the stated numbers in various statistical data refer only to registered individuals (and it is a known fact that this number is much higher), the creation of a random representative sample is very hard, even impossible. Therefore, this research was not based on a representative sample but on an convenience sample. The questionnaire was posted on an internet platform for the collection of data, Google Forms, and offered in this form to be filled in. The recruitment of respondents who participated in the research was conducted through numerous organisations of the Serbian diaspora, embassies, and church organisations, which forwarded the link of the questionnaire to people from their bases, and through ads on social networks, as well as through personal recommendations.

As far as the socio-demographic characteristics of the sample are considered (Table 2 ), around $60 \%$ of our respondents are female. Over $60 \%$ of our respondents finished undergraduate studies, whilst around $40 \%$ of them finished postgraduate studies. $60 \%$ of our respondents live with their partners, whereby $40 \%$ do not. When it comes to children, $60 \%$ of them do not have any children. When the employment status is taken into account, $80 \%$ of the respondents are employed, and $70 \%$ are satisfied with their material situation. As for coming back to Serbia, a half of the respondents declared that they do not plan to come back, a third is thinking about it, and only $15 \%$ will come back for sure. The arithmetic mean of respondents' age is 36.49 , and of the time spent abroad 9.87 years.

Table 2

Sample structure

\begin{tabular}{|l|l|c|c|}
\cline { 3 - 4 } \multicolumn{2}{c|}{} & $\mathrm{N}$ & $\%$ \\
\hline \multirow{3}{*}{ Gender } & Male & 112 & 34.3 \\
\cline { 2 - 4 } & Female & 215 & 65.7 \\
\hline \multirow{3}{*}{ Education } & Undergraduate & 200 & 61.2 \\
\cline { 2 - 4 } & Postgraduate & 127 & 38.8 \\
\hline
\end{tabular}

${ }^{4}$ The term 'diaspora' is defined in the Law on Diaspora and Serbs in the Region (2011) and refers to the citizens of Serbia living abroad and members of the Serbian people, immigrants from the territory of the Republic of Serbia and their descendants. Following this definition, those who live abroad at least one year have been considered migrants in our study. Furthermore, in this research, the International Standard Classification of Education is used, which equates the concept of highly educated people with tertiary education (ISCED, 2011). In that sense, our sample consists of individuals who have completed tertiary education (higher vocational school, high vocational school, Bachelor, Master's, specialist and PhD studies). 


\begin{tabular}{|l|l|c|c|}
\hline \multirow{3}{*}{ Partner relationship } & Yes & 196 & 60 \\
\cline { 2 - 4 } & No & 131 & 40 \\
\hline \multirow{3}{*}{ Children } & Yes & 133 & 40.7 \\
\cline { 2 - 4 } & No & 194 & 59.3 \\
\hline \multirow{3}{*}{ Employment } & Yes & 261 & 20.2 \\
\cline { 2 - 4 } & No & 66 & 79.8 \\
\hline \multirow{3}{*}{ Coming back to Serbia } & Satisfied & 229 & 70 \\
\cline { 2 - 4 } & Dissatisfied & 60 & 18.3 \\
\cline { 2 - 4 } & Don't know & 38 & 11.6 \\
\hline & Yes, definitely & 51 & 15.6 \\
\cline { 2 - 4 } & Thinking about it & 107 & 32.7 \\
\cline { 2 - 4 } & No, definitely & 169 & 51.7 \\
\hline
\end{tabular}

Source: Author's own study.

\section{Survey Results and Analysis}

Table 3 shows the arithmetic means of the obtained answers, which refer to the expression of value orientations.

Expression of value orientations

\begin{tabular}{|l|c|c|c|c|}
\hline \multicolumn{1}{|c|}{$\mathrm{N}=327$} & $\min$ & $\max$ & mean & sd \\
\hline Openness to the world & 6 & 30 & 21.96 & 4.83 \\
\hline Religiousness & 6 & 30 & 14.86 & 6.86 \\
\hline Egalitarianism & 6 & 30 & 15.46 & 4.64 \\
\hline Conformism & 6 & 25 & 10.02 & 3.46 \\
\hline Authoritarianism & 6 & 29 & 12.62 & 4.63 \\
\hline Gender equality & 6 & 30 & 27.09 & 3.71 \\
\hline General activism & 6 & 28 & 13.57 & 4.35 \\
\hline Social activism & 6 & 30 & 16.08 & 5.21 \\
\hline Traditional values & 28 & 108 & 64.54 & 16.07 \\
\hline Survival values & 45 & 98 & 72,56 & 9.98 \\
\hline Social distance & 13 & 76 & 35.21 & 12.38 \\
\hline
\end{tabular}

Source: Author's own study. 
Expression of value orientations

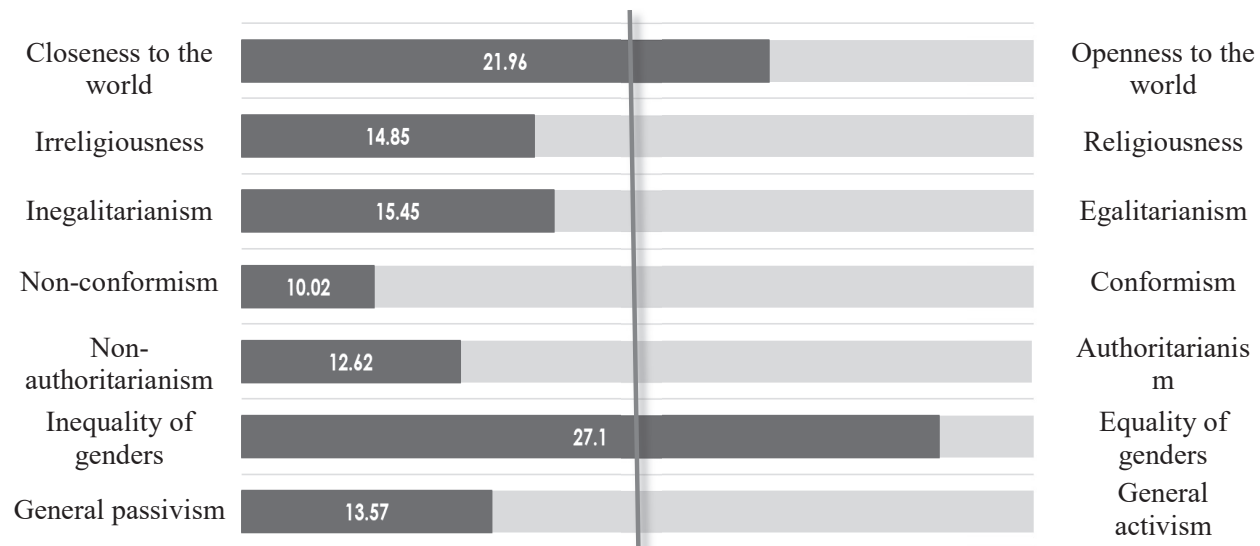

Social passivism

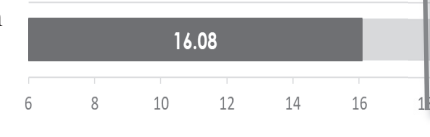

activism

Social activism

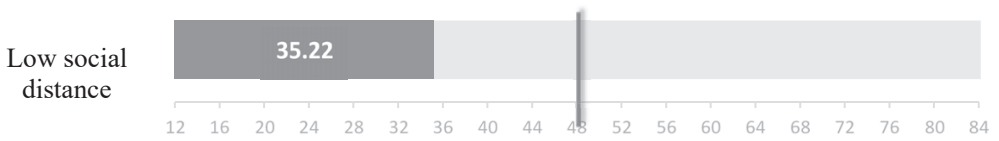

High social

distance

Secular-rational values

64.54

Traditional

values

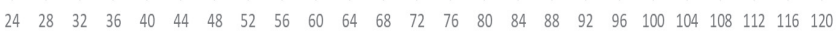

Self-expression
values
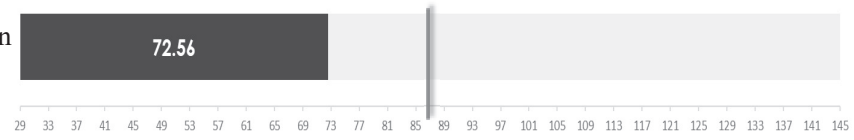

Survival

values

Source: Author's own study.

Within our sample, only two value orientations are expressed above the average on the scales that measure them: openness to the world $(\mathrm{m}=21.96, \mathrm{sd}=4.83)$ and gender equality $(\mathrm{m}=27.09, \mathrm{sd}=3.71)$. On the other hand, the least expressed value orientation is conformism $(\mathrm{m}=10.02, \mathrm{sd}=3.46)$. Lower scores are also expressed when it comes to religiousness $(\mathrm{m}=14.86, \mathrm{sd}=6.86)$ and authoritarianism $(\mathrm{m}=12.62$, $\mathrm{sd}=4.63$ ). Regarding the scores for traditional, that is, secular-rational values and survival, that is, self-expresion values, the bigger score goes in favour of traditional and survival values. As it can be seen in Table 3, our sample is characterised by 
expressed secular-rational values $(\mathrm{m}=64.54, \mathrm{sd}=16.07)$ and self-expresion values $(\mathrm{m}=72.56, \mathrm{sd}=9.98)$. As far as the expression of social distance towards marginalised groups is concerned, which characterised our sample, the results show that the social distance in our sample is at a low level $(\mathrm{m}=35.21, \mathrm{sd}=12.38)$, being that a higher score indicates a higher degree of social distance.

Given that the graphical presentation gives a much more illustrative image of the obtained results, we have opted for this kind of display as well (Graph 1). The line dividing the scales presents a theoretical mean value which divides each scale into two poles.

The results of different studies in Serbia indicate the dominant expression of materialistic orientation in Serbia. Pantić (2003), for example, determined by applying Inglehart's scale in his research that postmaterialistic values in 1996 were characteristic for $23 \%$ of Serbian citizens. Kuzmanović and Petrović (2007) determined that high-school students from Belgrade highlight, as the most desirable social goals, employment and citizens' standard of living (58\%), which, in fact, refers to the materialistic goals. Another author reached similar conclusions. Namely, in his research, on a representative sample of the Serbian population, Pavlović (2009) determined that $49 \%$ of respondents were characterised by materialistic values, and only $6 \%$ by postmaterialistic. Things are not different when it comes to highly educated members ether, as the research conducted by Maksić and Pavlović (2012), based on data from the fourth wave of the EVS that was in Serbia conducted in 2008 on a representative sample shows. The authors have shown that the most educated respondents in the sample value less the material aspects of the job - the amount of earnings and job security, but the differences in terms of evaluating the initiative at the workplace and participation in decision making between them and those who have lower level of education are not significant. The most educated respondents, or as the authors call them - the social elite, are less inclined to accept the traditional division of gender roles, they are more interested in politics and politically more active (however, these differences are small). On the other hand, the highly educated have the same relationship to the general principles of freedom and equality and equally accept the absolutist moral principles as well as the respondents with lower levels of education. A significant difference, regarding the controversial issues, appears only in degree of approval of euthanasia (which is more accepted within highly educated), but in the remaining cases (such as the approval of homosexuality) differences are not significant. The authors further point out that although some differences between those with higher and lower levels of education are noticed, they are not ether large nor consistent, and especially surprising is the absence of significant differences where they could be expected, and which would imply higher levels of tolerance and liberalism in the group of the highly educated. Such results are also in accordance with the results obtained from other researchers in the area (Đorđević, Gojkov, Stojanović 
2009; Mitrović 2010; Stanković 2010; Cvetićanin 2010; Selimović 2014), so the authors conclude that the similarities between highly educated and those with lower level of education in Serbia overcome the differences that exist between them, and the explanation for this tendency find in the context of transition and other, unfavourable social events, economic and political insecurities, which have marked Serbia since the 1990's. Specifically, the social conditions of the transition period in Serbian society favoured the development of materialistic values (Pero 2006). Moreover, the legacy of tradition and politically encouraged processes of retraditionalization favoured the revival of pre-modern values. These results also speak in favour of Inglehart's theses that when it comes to postmaterialistic values, education presents only one of the indicators of the level of economic security in the formative period and doesn't have importance when it comes to the formation of secular-rational and self-expression values (Abramson, Inglehart 1992; Inglehart 1971; Inglehart, Flanagan 1987; Inglehart, Abramson 1999; Inglehart, Baker 2000). Furthermore, if the postmaterialistic values are adopted later in life (primarily as a result of education of the individual), they are to a greater extent subject to change (Rimac, 1997, Pero 2006).

Even though these results show that Serbia belongs to the group of mostly materialistically oriented countries, what is evident is that our sample is characterised by the opposite end of these values - postmaterialism, which comes as no surprise if we take into account that survival values place emphasis on economic and physical security (Inglehart 1971; Inglehart, Flanagan 1987; Abramson, Inglehart 1992; Inglehart, Abramson 1999; Inglehart, Baker 2000, Inglehart, Welzel 2005 ) and $70 \%$ of our respondents said that they were satisfied with their material situation, and as we have mentioned before they left an economically unstable and devastated country which is in accordance with the Inglehart's scarcity hypothesis.

When it comes to authoritarianism, the results of the research conducted by Golubović, Kuzmanović and Vasović (1995) on Serbian population should be mentioned. The results speak of a very high level of authoritarianism of respondents and the authors point out that this trait originates from the traditional, patriarchal culture which is characteristic for Serbia. Similar results were obtained by Rot and Havelka (1973) who pointed out that this trait was not the consequence of an inborn personality trait, but from acquired beliefs which could be changed with the change of one's surroundings. Authoritarianism is a cognitive trait that arises on the basis of learned concepts that are prevalent in certain cultures or subcultures and presents a reflection of the current conditions in which an individual is found because it is rational for the individual to be directed to power and to be obedient to the authorities in certain social circumstances (Greenstein 1987). Results gained in our research, which show that our sample characterizes a low level of authoritarianism, are in accordance with Inglehart's theory and his postmatialistic 
approach (Inglehart 1971; Inglehart, Flanagan 1987; Abramson, Inglehart 1992; Inglehart, Abramson 1999; Inglehart, Baker 2000), where it is emphasized that the manifested secular-rational and self-expression values are a reflection of a culture in which survival is certain, thus reflecting anti-discrimination and humanistic tendencies, and resistance to traditional norms and externally imposed authority (Pavlović 2009).

As far as the levels of social distance is concerned, it is important to mention that a large number of researches indicate that there is a positive correlation between ethnic heterogeneity of family and friendly environment and a low level of social distance. This kind of research indicates that individuals who have members of different ethnic groups in their environment express more tolerance towards difference (Hodson et al. 1994 as cited in Haneš 2012; Turjačanin 1999, 2004, 2005), and that ethnic heterogeneity of friendly environment is the most powerful and the most significant predictor of reducing prejudices and distance (Turjačanin 2007). Being that our sample consists of migrants, individuals who are undoubtedly surrounded by different social, ethnic and racial groups, a low level of social distance is not surprising.

Strong exposure to dominant value systems, and modernising effects of the educational system, great diversity in social contacts and exposure to different cultural models, influence individuals value systems (Pešić, 2016) and it's not surprising that value orientations of people from our sample got a unique, specific character, which includes greater openness towards the world, non-authoritarianism, egalitarianism and a more positive attitude towards gender equality, and expressed postmaterialistic values. Therefore, our assumption is that the results of our research could be the consequence of a migrant lifestyle. The results of the research on value orientations of Nepali migrants compared to non-migrants, which was conducted by Williams and associates (2013), also indicate that migrants have become generally more open towards the world and novelties which are characteristic for the host society, and also attribute these changes to the experience of migrants which is developed after their contact with the culture of their destination and a transnational lifestyle which exposes migrants to various individuals and lifestyles. Massey and Sanchez (2004) found in their ethnographic research of the second generation of immigrants in Philadelphia, New York and New Jersey that the transnational identities are being formed. Haller and Landlot (2005) in their longitudinal study of the second generation of immigrants in Miami and San Diego also found that transnational patterns could be observed. These patterns are coloured by social class, education, nationality and ethnicity but are also unique and specific and that further study of these changes are significant for understanding the process of forming a transnational identity. Another qualitative research focused on discovering transnational patterns, in this case Russian immigrants in Scotland (Mamattah, 2006) showed that these patterns develop, and represent a kind of a combination of elements 
of home and host country. In this sense, our findings are in accordance with the new approach in studying migrations - transnationalism which points out, as it has been mentioned in the theoretical part of the paper, that, within their transnational social fields, migrants build and develop strong networks which connect their home and host countries through their everyday activities, thus creating new social fields which transcend national borders. Bitinas (1971 as cited in Javkovska, Barakoska 2014), while analysing the mechanisms of forming of value orientations, explains that the process of forming of value orientations is a process of transferring of objective values in subjective with meaning for a certain individual, and in that sense the development of value orientations is an indicator of the degree of socialization of the individual. Linking old and new identities is a necessity that facilitates migrants to deal with all the positive and negative changes that follow their life paths (Mamattah, 2006).

Transnationalism emphasises multiple forms of migrants embedding through which they stay connected and actively participate in both home and host countries' political, economic, social and cultural environments (Glick Schiller et al. 1995; Glick Schiller 2010; Faist 2010; Waldinger 2008, 2013; Pavlov, Predojević Drespić, Milutinović, 2013; Pajvančić - Cizelj 2015). These conditions contribute to the development of specific value orientations and extremely elastic and fluid transmigrant identities, which are constantly shaped and reshaped by different forms of influence of different societies. As a result, in today's era of globalization, assume some authors (Levitt, 2004), transnational lifestyle ceases to be a rarity, but becomes the rule.

\section{Limitations and recommendations}

The main limitation of this study is the sample size, and consequently, its representativeness. The aim of our research was to analyze a large number of different variables and to test their exploratory power in relation to the subject of this paper. Further studies are necessary to confirm these findings. In this regard, indicated results and information should be considered only as an indication of possible tendencies that require additional research and more complex analysis, for which, unfortunately, the data currently available to us does not provide enough material.

In addition to all the theoretical and methodological limitations and objections that can be given to this study, we believe that our research is valuable as the first to provide empirical evidence on the preference of value orientations of highly educated members of Serbian diaspora. Our findings raise many questions. Therefore, we believe that our findings could serve as the basis and inspiration for future research which could bring new knowledge regarding the nature and dynamic of indicated tendencies. One of the recommendations for future research is a larger sample (ideally, if possible, representative), and including members of diaspora 
with a lower level of education but also the non-immigrant or domicile population. Such approach would provide a comparative study base on which it would be possible to see more clearly and precisely the differences identified in our analysis. Additionally, we believe that applying the qualitative approach would contribute to a better and deeper understanding of the process of forming a transnational identity and discovering ways of linking old and new identities.

\section{Conclusion}

In this paper we have tried to examine value orientations with the members of the Serbian highly educated emigrants. Theoretical framework on which we have based this research represent the standpoint that value orientations are relatively stable, but also predispositions which are prone to changes, and the new approach in the study of migrations - transnationalism.

On the basis of the research results we have determined that the Serbian highly educated emigrants are characterised by openness towards the world, expressed secular-rational and self-expression values. This means that they put less emphasis on the significance of religion, traditional values and the respect of authority, and that they are characterised by expressed tolerance towards different social groups and a very positive attitude towards gender equality. In the theoretical comparison with earlier studies which refer to the population in Serbia, we have determined that value orientations of our sample are different in relation to the domestic population, including highly educated. Specific life paths, exposure to different cultural models and, a great variety of social contacts, and ethnic heterogeneity of the friendly environment along with higher education which makes them more prone to changes, also influenced the fact that value systems and value orientations of our respondents receive a unique, specific character as a consequence of the migrant lifestyle. These findings are in accordance with the new approach in the study of migrations - transnationalism. Transnational lifestyle exposes migrants to the most diverse people and the most diverse forms of influence of different societies, which also contributes to the development of transmigrant identities.

Considering the limits that surround our research, the understanding of the phenomenon of transnationalism has not been our focus, but our findings can be one of the first steps towards the attempt to identify it in the context of Serbian migrants. It is our strong belief that the transnationalist perspective in the future research will enable a better understanding of the activities which occur within global interaction, on both global and local levels. Surely, all of the aforementioned implications, results and data should be observed only as indications of possible relations, which would require a further analysis, considering the explorative character and limits which have marked this research. 
In the end, we would like to point out that this study tends to contribute to a more culturally oriented research approach in the study of migrations. Values and value orientations are an important part of the cultural capital. Knowing about them helps us discover and understand political and social attitudes of our emigrants, their expectations and desires, and the complexity of their transnational identities and the feeling of belonging which they develop. In the modern world, marked by the processes of globalisation, life stories which are not related to the borders of a certain national state have already become a normal occurrence. More and more people belong simultaneously to two or more cultures and societies, and these affiliations are not mutually exclusive.

\section{References}

Abramson, P. R., Inglehart, R. (1992), Generational Replacement and Value Change in Eight West European Societies, "British Journal of Political Science" Vol. 22, Issue 2, pp.183-228.

Alargić, D. Đ. (2012), Karakteristike pojedinca kao činioci sistema vrednosti pripadnika vojske Srbije, Doctoral dissertation. Beograd: Univerasity of Belgrade.

Law on diaspora and Serbs in the region (2011), Official Gazette RS, no. 88/09.

Basch, L., Glick Schiller, N., Szanton-Blanc, C. (1994). Nations unbound: Transnational projects and the deterritorialized nation-state. New York: Gordon and Breach.

Berry, J.W. (1997), Immigration, Acculturation, and Adaptation, "Applied psychology: an international review" Vol. 46 Issue 1, pp. 5-68.

Berry, J.W. (2002), The Psychology of Immigration, "Journal of Social Issues" Vol. 57 Issue 3, pp. 615-631.

Berry, J.W. (2005), Acculturation: Living successfully in two cultures, "International Journal of Intercultural Relations" Vol. 2, pp. 697-712.

Bešić, M. (2014), Tranzicione traume i promene vrednosnih orijentacija - generacijski pristup, Komparativna empirijska studija vrednosti u zemljama bivše Jugoslavije. Projekat: Politički identitet Srbije u regionalnom i globalnom kontekstu. Beograd: Fakultet političkih nauka.

Bhugra, D. (2004), Migration, distress and cultural identity, "British Medical Bulletin" Vol. 69, pp. 129-141.

Bhugra, D., Becker, M. A. (2005), Migration, cultural bereavement and cultural identity, "World Psychiatry" (Special article) Vol. 4 Issue 1, pp.18-24.

Bobić, M. (2009), Dijaspora kao ekonomski i socijalni kapital Srbije. "Sociološki pregled” Vol. 43 Issue 3, pp. 361-378.

Bobić, M., Babović, M. (2013), Međunarodne migracije u Srbiji - Stanje i politke. "Sociologija" Vol. 55 Issue 2, pp. 209-228.

Bogardus, E.S. (1933), A Social Distance Scale, "Sociology and Social Research" Vol. 17, pp. 265-271.

Chukwujekwu, C.D., Chukwujekwu C.J., Olose E.O. (2016), Relationship Between Socio-demographic Variables and Social Distance Towards the Mentally Ill, "American Journal of Psychiatry and Neuroscience" Vol. 4 Issue 3, pp. 52-56.

Cvetićanin, N. (2010), Proces konstituisanja političke i društvene elite u srpskom društvu problem diskontinuiteta i „fluktuirajućeg legitimiteta“. "Nacionalni interes” Vol. 6 Issue 3, pp. 107-146. 
Davis, D., Davenport, C. (1999), Assessing the Validity of the Postmaterialism Index. "American Political Science Review" Vol. 93 Issue 3, pp. 649-664.

De Haas, H. (2005), International Migration, Remittances and Development: Myths and Facts, “Third World Quarterly” Vol. 26 Issue 8, pp. 1269-1284.

Dinić, J. (2016), Neki pokušaji sistematizacije teorijskih socio-ekonomskih uzroka migracija u savremenom društvu, "Stanovništvo jugoistočne Srbije: Odliv mozgova - uzroci i posledice po nacionalni razvoj i identitet” (Book of proceedings), Centar za naučna istraživanja, SANU, University of Niš, pp. 27-41.

Dinić, J. (2017), Značaj proučavanja vrednosti i vrednosnih orijentacija migranata, “Godišnjak za sociologiju” Vol. 12 Issue 17, pp. 67-86.

Đorđević, B., Gojkov G.,. Stojanović, A. (2009), Vrednosti potencijalne društvene elite. In: Gojkov, G. (ed.), Daroviti i društvena elita. Vršac: Visoka škola strukovnih studija za obrazovanje vaspitača „Mihailo Palov“.

Faist, T. (2010), Diaspora and transnationalism: What kind of dance partners? In: Baubock, R., Faist, T. (eds.) Diaspora and Transnationalism: Concepts, Theories and Methods. Amsterdam: IMISCOE Research, Amsterdam University Press.

Flanagan, S.C., Lee, A.R. (2003), The New Politics, Culture Wars, and the Authoritarian-Libertarian Value Change in Advanced Industrial Democracies, "Comparative Political Studies" Vol. 36, pp. 235-70.

Gavrilović, D., Stjepanović, Zaharijevski, D. (2012), Tradicionalne i moderne vrednosti u tranzicionoj Srbiji. “Teme” Vol. 34 Issue 3, pp. 1087-1102.

Glick Schiller, N. (2010), A global perspective on transnational migration: Theorising migration without methodological nationalism. In: Baubock, R., Faist, T. (eds.) Diaspora and Transnationalism: Concepts, Theories and Methods. Amsterdam: IMISCOE Research, Amsterdam University Press.

Glick Schiller, N., Basch, L., Szanton Blanc, C. (1995), From Immigrant to Transmigrant: Theorizing Transnational Migration, "Anthropological quarterly” Vol. 68 Issue 1, pp. 48-63.

Golubović, Z., Kuzmanović, B., Vasović M. (1995), Društveni karakter i društvene promene u svetlu nacionalnih sukoba. Beograd: Filip Višnjić i Institut za filozofiju i društvenu teoriju.

Grečić, V. (2002), The Role of Migrant Professionals in the Process of Transition in Yugoslavia, "International problems" Vol. 54 Issue 3.

Grečić, V. (2009), Bolje korišćenje talenta kao faktor povećanja konkurentnosti. In: Ekonomski-finansijski odnosi Srbije sa inostranstvom: Nužnost nove strategije. Beograd: Naučno društvo ekonomista, Akademija ekonomskih nauka, Ekonomski fakultet.

Greenstein, F. I. (1987), Personality and Politics: Problems of Evidence, Inference and Conceptualization. Princeton, New Jersey: Princeton University Press.

Haller, W., Landolt, P. (2005), The transnational dimensions of identity formation: adult children of immigrants in Miami. "Ethnic and Racial Studies" Vol. 2 Issue 6, pp. 182-214.

Haneš, O. (2012), Sociodemografske karakteristike, socijalne distance i stereotipi kod studenata u Banjaluci, "Primenjena psihologija" Vol. 2012/1, pp. 59-79.

Hansen, O., Tol, R. (2003), A refined Inglehart index of materialism and postmaterialism, "American Political Science Review" Vol. 73, 155-169.

Inglehart, R. (1971), The Silent Revolution in Europe: Intergenerational Change in Post-industrial Societies, "American Political Science Review” Vol. 65 Issue 4, pp. 991-1017.

Inglehart, R., Abramson P. R. (1999), Measuring Postmaterialism, “The American Political Science Review" Vol. 93 Issue 3, pp. 665-677. 
Inglehart, R., Baker, W. E. (2000), Modernization, Cultural Change, and the Persistence of Traditional Values, "American Sociological Review” Vol. 65 Issue 1, pp. 19-51.

Inglehart, R., Flanagan, S. C. (1987), Value change in Industrial Societies, "The American Political Science Review" Vol. 81 Issue 4, pp. 1289-1319.

Inglehart, R., Welzel, C. (2005) Modernization, Cultural Change and Democracy. New York and Cambridge: Cambridge University Press. ISCED - International Standard Classification of Education (2011), UNESCO Institute for Statistics (UIS), http://uis.unesco.org/sites/ default/files/documents/international-standard-classification-of-education-isced-2011-en. pdf [Accessed: 16.02.2016].

Jovkovska, A., Barakoska, A. (2014), The role of education in the formation of values and value orientations among adolescents. "International Journal of Cognitive Research in Science, Engineering and Education" Vol. 2 Issue 2, pp. 21-28.

Kivisto, P. (2001), Theorizing Transnational Migration: A Critical Review of Current Efforts, "Ethnic and Racial Studies" Vol. 24 Issue 4, pp. 549-577.

Kurekova, L. (2011), Theories of migration: Conceptual review and empirical testing in the context of the EU East-West flows. Interdisciplinary conference on Migration. Economic Change, Social Challenge. April 6-9, 2011, University College London, https://cream.conference-services.net/resources/952/2371/pdf/MECSC2011_0139_paper.pdf [Accessed: 22.07.2017].

Kuzmanović, B. (1995), Uvodna razmatranja za istraživanje promena vrednosnih orijentacija mladih u Srbiji, "Psihološka istraživanja" Vol. 7, pp. 9-15.

Kuzmanović, B., Petrović N. (2007), Vrednosni ciljevi kao činioci političkih stavova i mnenja mladih. Beograd: Filozofski fakultet. L

Lazić, M. (2000), Rekapitulacija. In: Lazić, M. (ed.) Račji hod: Srbija u transformacijskim procesima. Beograd: Filip Višnjić

Levitt, P. (2004) Transnational Migrants: When "Home" Means More Than One Country. "Migration Policy Institute Online Journal”, https://www.migrationpolicy.org/article/transnational-migrants-when-home-means-more-one-country [Accessed: 05.02.2017].

Maksić, S., Pavlović, Z. (2012), Vrednosni profil društvene elite u Srbiji. In: Grozdanka, G., Stojanović, A. (eds.) Darovitost i moralnost. Visoka škola strukovnih studija za obrazovanje vaspitača „Mihailo Palov“, Universitatea de Vest „Aurel Vlaicu“, Univerzitet „Sv. Kliment Ohridski“ and REVIVIS.

Maldini, P. (2006), Demokratizacija i vrijednosne orijentacije u hrvatskom društvu. "Anali hrvatskog politiloškog društva" Vol. 2 Issue 1, pp 81-103.

Mamattah, S. (2006), Migration and Transnationalism: the Complete Picture? A Case Study of Russians Living in Scotland. "eSharp" Vol. 6 Issue 2, pp. 1-22.

Massey, D. S., Sanchez, M. (2004), Transnational Identity and Behaviour: An Ethnographic Comparison of First and Second Generation Latino Immigrants. Paper presented at the annual meeting of the American Sociological Association. 2009-05-26, San Francisco, http:// www.allacademic.com/meta/p110907_index.html [Accessed: 14.05.2017].

Mitrović, Lj. (2010), Nova buržoazija i njena elita u društvu perifernog kapitalizma. "Nacionalni interes" Vol. 6 Issue 3, pp. 249-270.

Nikitović, V. (2011), Može li izbeglička populacija u Srbiji značajno uticati na njenu demografsku budućnost? In: Penev, G.(ed.) Migracije, krize i ratni sukobi na Balkanu s kraja 20. veka. Beograd: Društvo demografa Srbije, DémoBalk.

Norris, P., Inglehart, R. (2009), Rising Tide - Gender Equality and Cultural Change around the World. Cambridge University Press. 
Pajvančić-Cizelj, A. (2015), Koncept globalnog grada kao pristup razumevanju savremenih obrazaca globalizacije i urbanizacije, Doctoral dissertation. Novi Sad: University of Novi Sad.

Pantić, D. (2003), Budućnost tranzicije u Srbiji zavisno od promena vrednosti. In: Promena vrednosti i tranzicija u Srbiji: pogled u budućnost - okrugli sto. Beograd: Fridrih Ebert Stiftung, Institut društvenih nauka.

Pavlov, T., (2009), Migracioni potencijal Srbije. Beograd: Grupa 484.

Pavlov, T., Predojević Despić, J., Milutinović, S. (2013), Transnational entrepreneurship: Experiences of migrant-returnees to Serbia, "Sociologija" Vol. 55, Issue 2, pp. 261-282.

Pavlović, Z. (2009), Is there a sociodemographic model of acceptance of postmaterialist values? The case of Serbia "Sociologija" Vol. 51 Issue 2, pp. 177-188.

Pešić, J. (2016), Vrednosne orijentacije u post-socijalističkim društvima Srbije i Hrvatske. Doctoral dissertation. Belgrade: University of Belgrade.

Portes A. (1997), Immigration theory for a new century: some problems and opportunities, "International Migration Review" Vol. 31 issue 4, pp. 799-825.

Predojević-Despić, J., (2009), Migrantske mreže - nezaobilazna perspektiva u proučavanju savremenih međunarodnih migracija, "Sociološki pregled” Vol. 43 Issue 2, pp. 209-229.

Rimac, I. (1997), O nekim aspektima valjanosti postmaterijalističkog koncepta društvenih vrijednosti. "Društvena istraživanja" Vol. 6 Issue 32, pp. 677-694.

Robinson, W. (1998), Beyond Nation-State Paradigms: Globalization, Sociology, and the Challenge of Transnational Studies, "Sociological Forum” Vol. 13 Issue 4, pp. 561-594.

Rokeach, M. (1968), A Theory of Organization and Change Within Value-Attitude Systems. "Journal of Social Issues" Vol. 24 Issue 1, pp. 13-33.

Rot, N., Havelka N. (1973), Nacionalna vezanost i vrednosti kod srednjoškolske omladine. Beograd: Institut za psihologiju i IDN.

Rudnev M. (2014), Value Adaptation Among Intra-European Migrants: Role of Country of Birth and Country of Residence, "Journal of Cross-Cultural Psychology" Vol. 47 Issue 10, pp. 1-17.

Selimović, A. (2014), Tipološki pristup dimenzijama ideološke orijentacije. Doctoral dissertation. Novi Sad: Univerzitey of Novi Sad.

Stanković, V. (2010), Društvena elita u Srbiji - preobražaj i prohodnost u poslednjih dvadeset godina. "Nacionalni interes" Vol. 6 Issue 3, pp. 469-490.

Turjačanin, V. (1999), Etnička distanca kod mladih u Republici Srpskoj, "Empirijska istraživanja u psihologiji 5” (Book of apstracts) Beograd: Filozofski fakultet - Institut za psihologiju.

Turjačanin, V. (2004), Etnički stereotipi mladih bošnjačke i srpske nacionalnosti u BiH. Banja Luka: Filozofski fakultet.

Turjačanin, V. (2005). Nacionalni stavovi mladih bošnjačke i srpske nacionalnosti u BiH. Banja Luka: Filozofski fakultet.

Turjačanin, V. (2007), Psihosocijalni prostor i etnički odnosi mladih. Banja Luka: Filozofski fakultet.

Vertovec, S. (2001), Transnationalism and Identity, "Journal of Ethnic and Migration Studies" Vol. 27 Issue 4, pp. 573-582.

Waldinger, R. (2008), Between "Here" and "There": Immigrant Cross-Border Activities and Loyalties, "International Migration Review - IMR" Vol. 42 Issue 1, pp. 3-29.

Waldinger, R. (2013), Immigrant transnationalism, "Current Sociology” Vol. 61 Issue 5-6, pp. 756-777.

Williams, N. E., Thornton, A., Young-DeMarco, L. C. (2013), Migrant Values and Beliefs: How Are They Different and How Do They Change? "Journal of Ethnic and Migration Studies" Vol. 40 Issue 5, pp. 796-813. 